\title{
OBITUARY
}

\section{Professor T. W. Rhys Davids}

On 20th January, 1922, died one well known at the School of Oriental Studies both for her work in Pali and her personal charm, Mrs. Bode; and on 27th December of the same year died Professor Rhys Davids, not only a great Oriental scholar, but a man who deserved the gratitude of the School as an earnest advocate of its foundation and as an unwearied promoter of schemes for the wise direction of its efforts.

Professor Rhys Davids was born on 12th May, 1843, at Colchester. His father was a leading Congregational Minister, and he showed in his book, Annals of Evangelical Nonconformity in Essex, that gift of patient enthusiasm, illuminating what would otherwise be dry details, which was a leading characteristic of his son.

Professor Rhys Davids was at school at Brighton, and gave up a good opening in the legal profession to go to the University of Breslau, where he learnt Sanskrit under Professor Stenzler, to whom, in 1880, he dedicated his Buddhist Birth Stories. At Breslau he learnt to value the German system of training students by research almost from the beginning of their study; whereas the system of the older English universities makes research the crown and reward of patient and thorough preparation. Each system has its merits and drawbacks; the training of Breslau prepared Professor Rhys Davids for that noble pioneer work in which the best are of necessity always beginners. In 1864 he entered the Ceylon Civil Service; and as Sanskrit had made Tamil and Simhalese easy to him, he was able to understand the natives and their views. The production, as evidence in a trial, of a Pali sacred text that no one present could read led to the work of his life by making him resolve to master the unknown language. Pali was, however, not entirely unknown to the world. Its study by Europeans began, as Professor Rhys Davids said later (in his contribution to the Presidential Address to the Philological Society in 1875, pp. 60-79), with an "Essai sur le Pali", 1826, by Eugène Burnouf \& Professor Lassen, and was carried on by Turnour in his edition of the 
Mahāramsa (of which only Vol. I was published), 1837-a work which Professor Rhys Davids called " the foundation of all Pali scholarship". Gogerly and others had used its documents. R. C. Childers, who left Ceylon in 1864, had begun his Dictionary (published 1872-5). Fausböll, at Copenhagen, had published the Dhammapada in Pali and Latin, and was editing the text of the Jataka. Scholars here and there were doing some work, but it was reserved for Professor Rhys Davids to make Buddhism a household word, and to make it not only a valuable part of special knowledge, but a necessary link in the mental history of mankind. In the Hibbert Lectures, 1881 (p. 187), Professor Rhys Davids gave a memorable picture of the dying monk, Yātrāmullē Unnānsē, who came often some distance on foot to use his last strength in teaching his eager European pupil the Pali language, and in seeking, not in vain, to inspire him with a love of Buddhist ideas and zeal for making them known to the world. "There was an indescribable attraction about him, a simplicity, a high-mindedness, that filled me with reverence." Rhys Davids often spoke of him as "the best man I ever knew". In 1877 a difference with the authorities on a question concerning native rights led him to resign his post in the Ceylon Civil Service. He returned to England and, entering the Middle Temple, read for the Bar, but never practised. His legal training was, however, not wasted; it had taught him to weigh evidence and to suspend judgment in the difficult questions of scholarship. A friend says of him at this time: "He was then vigorous both in body and mind, sitting up very late at night working and playing tennis in the Temple garden in the afternoon. He knew everybody and was a charming companion, witty, humorous, and most kind. It was the same at the club ; I used to dine with him almost every night, and the party was not complete without him."

Vigorous he doubtless was, but it took some years to recover morally from the enmity that upset his career and physically from the malaria left by the climate of Ceylon, and he often had to work through much pain.

In the Hibbert Lectures, 1881, he was able to announce the founding of the Pali Text Society, of which the first committee contained the honoured names of Professor Fausböll, Dr. Oldenberg, Dr. Morris, and M. Senart, with himself as chairman. With his usual practical genius, he had reckoned that in so many volumes of a certain size and type the sacred texts could be published ; and his power of seeing quite clearly what he aimed at brought both workers and money in 
unfailing support for forty years, in which time, after carrying out the original plan, he was able to enlarge the sphere of publication. A friend remarks his genius for finance and his power of interesting rich people. This came from the clearness of his aims, which showed givers that their money would not be wasted, and also from the instinctive sense that he himself shrank from no sacrifice for the things for which he asked the help of others. He had now definitely given himself to Oriental work. In 1882 (till 1904) he became Professor of Pali in University College, London-an honorary post; and soon afterwards, as Secretary and Librarian of the Royal Asiatic Society (1885 to 1904), he had full scope for his energies; he filled the Society with new life, gave freshness to its debates, and a purpose to its energies. Under his auspices it published its series of Translations and of Monographs, and shared in the planning of the Indian Text Series. His labours were added to by his share in founding the British Academy. At the same time his own scholarly work was continued. He had already published, besides several papers, his manual on Buddhism, 1878, Buddhist Birth Stories, 1880, Buddhist Suttas (Sacred Books of the East, vol. xi); and in 1881 he published in the same series three volumes of Vinaya Texts with the collaboration of Professor Oldenberg. His friendship with the latter began with an act of generosity. Professor Oldenberg came to consult him about an edition of the Dipavamșa he was wishing to make, and Professor Rhys Davids at once handed over to him all the material he had himself amassed for the same purpose. In The Questions of King Milinda (S.B.E., 1890-4) he translated a text which was, in his estimation, "the masterpiece of Indian prose" and (as a book of apologetic controversy) "the best in point of style that had then been written in any country." He edited with Dr. J. E. Carpenter the Dìgha-Nikāya, i and ii (1890-1911), with the first volume of its commentary, the Sumangala Vilāsinī (1886).

He had in the Asiatic Society an invaluable helper in Miss C. Hughes, the Assistant Secretary (Mrs. W. Frazer), who succeeded him in 1904 as Secretary ; and he had loyal support and co-operation from many distinguished scholars and friends; yet the toils he had undertaken might well have overwhelmed him if it had not been that in 1894 his power was doubled by his marriage with Caroline Augusta Foley, whose largeness of heart and brain and highly disciplined intellect made her a fit partner in so full a life. Three children were born to them; two daughters and a son, Arthur, whose brilliant promise 
as Captain of Eton and as a fighter of distinction in the Air Force met in 1917 its fulfilment in the noble sacrifice of his young life. Mrs. Rhys Davids' great labours in the field of Buddhist Psychology and Ethics, which she made her own, did not hinder her helping her husband in all departments of his work, especially the Pali Text Society; and all her own work in like manner bears the impress of their united minds.

Their marriage was soon followed by his journey to America, 1894-5, to give lectures, which were published under the title Buddhism: Its History and Literature (New York, 1896). A journey to India, in 1899, gave him the delight not only of visiting the scenes of Buddha's life, but of getting into touch with those who by authority, high position, or intellect could help in his cherished scheme of bringing the mental force of India to bear on its own history. As usual, he had a definite aim, the publishing of texts which throw light on Indian history ; but, though he brought the plan into being, he left its carrying out in other hands. The immediate result of the journey was Buddhist India, written "from the point of view not so much of the Brahmin as of the Rajput", with evidence collected, a good deal of it, for the first time and necessarily imperfect, yet so suggestive and lightbringing that if the advocates of Brahmanic views refuse to weigh it, " there is but one course open, and that is to declare war, always with the deepest respect for those who hold them, against such views. They are not compatible with historical methods."

To his books must be added many papers in the Journal of the Royal Asiatic Society, and those read before Oriental Congresses and other meetings. As another paper in this number of the Bulletin deals with the result of his work, no attempt has been made here to describe or discuss any of his writings, fascinating as the theme would be.

The Hibbert lectures and the American lectures show his gift as a lecturer, of making knowledge clear and delightful, and of rising to high powers of thought and moral dignity, and of carrying his hearers with him in a quickened life. "I went, never having heard of Pali before, and went away almost persuaded to take up the study of Pali at once," said one who was by no means disposed to listen to lectures gladly.

A great change in his life followed in 1904 on his appointment as Professor of Comparative Religion in the Victoria University, Manchester, and he lectured on almost the whole field of the history of religion. In 1908 Early Buddhism expressed concisely some of the results to which he held most firmly in Buddhist thought. In 1910 
and 1921 he completed, with the help of Mrs. Rhys Davids, the translation of The Dialogues of the Buddha (Dīgha-Nikāya) in the Sacred Books of the Buddhists, of which he had published the first volume in 1899. It was largely due to his unselfish activities that some of his ripest scholarship now sees the light, not in any single work but scattered through the volumes of Hastings' Encyclopcedia of Religion and Ethics. He kept in touch with London by frequent and fatiguing visits to do his duty as President of the India Society and Member of the Council of the British Academy.

In 1915 he resigned his chair, and settled at Chipstead, in Surrey, where he lived a quiet scholar's life, suffering much pain, but working through it; and not, till near the end, giving up the games that had been his refreshment for so long and the quiet intercourse with friends in which the flow of his kindly humour and the flame of his enthusiasm had lost nothing of their strength.

He wrote reviews for the Manchester Guardian, and it would be happy if some of these could be collected; but the great work of his last years, with the help of Dr. W. Stede, was the final arranging of the material for the new Pali Dictionary. He lived to see nearly half the work issued, when hypostatic pneumonia, after two days' suffering, ended in a peaceful death on the 27th December, 1922.

There was never anything official or conventional in his dealings, and while he was working hard in the interests of scholarship he was not less interested in caring for all who had what he considered less than a fair chance in life-whether they were working men, or women suffering disabilities political or educational - he wished all to have their best possible development, and never failed to do his own part in giving it to them. He had a remarkable gift of sympathy. He could express himself vigorously, but would enter eagerly into the perhaps limited views of an objector, or even the reported views of a friend of the objector, and would treat them with a gentle courtesy not unmixed with humour. He could not be hard on any opinion where he felt the human being behind it, but his sympathetic understanding did not affect his own judgment. As was said of him, "he has the heart of a mountaineer," undauntedly pursuing his own course over all obstacles. "We work that others may do better than we" was his thought from the time when he praised Childers' Pali Dictionary, saying it was sure to be superseded (" for it was the foundation of the subsequent work . . . which has rendered it inadequate"), to his utterance about the new Pali Dictionary in which his high self- 
effacing spirit works to practical ends when he proposes not to wait for perfection, but to publish it as rapidly as possible, so as to preserve the proceeds of the sale of the first edition for the eventual issue of a second edition "which shall come nearer to our ideals of what a Pali dictionary should be". This was always his idea, that we should give our best to enable others to pass beyond us.

In his sharing his knowledge with his pupils and subordinating his own part in order to give value to their efforts he resembled another great English scholar, Professor Cowell; and the sloka in which Professor Cowell summed his life's work would be true of Professor Rhys Davids also :-

Gurur vicisyaḥ saralo yathā girau

Asevitah pānthajanena tișțhati |

Varam sa jïryen navaśișyasamśrito

Vṛtah svatantrair vițapair vaṭo yathā $\|^{1}$

He gave help freely both to individuals and to causes, and started the great works which cost so much, giving unsparingly of his own strength and time and effort. Yet his disinterestedness sprang from no unworldly indifference to wealth. He well knew what it meant in freedom and opportunity, and always advocated earnestly that scholars should not be expected to .work for nothing, but should receive the due reward of their labours. Of all pleasures that give health to body or mind (excepting, perhaps, such as involved death to creatures) he had keen appreciation, though he could do without them. He played golf, tennis, and billiards, and enjoyed social intercourse, of which he was the life.

Knowledge for him was not merely an accumulation of facts or of theories, but a living bond of union with the living, and a bringing back to consciousness the long fibres of life through which, though unrecognized by us, the past still speaks. For that reason it was never an effort to give up a theory or correct the statement of a fact. What he desired was the true living voice of all ages. "For," he said, "that knowledge of what man has been in distant times, in far-off lands, under the influence of ideas which at first sight seem to us so strange, will strengthen within us that reverence, sympathy, and love which must follow on a realization of the mysterious complexity

1 Translated by Professor Cowell :-

"High on his rock the lonely scholar stands,

A mountain pine that spreads no sheltering shade;

Rather grow old amid fresh student bands,

A banyan with its native colonnade." 
of being, past, present, and to come, that is wrapped up in every human life." That reverence, sympathy, and love was the centre of his being and the inspiration of his work.

"He was the proper friend-making, everywhere friend-finding soul; Fit for the sunshine, so it followed him; A happy tempered bringer of the best out of the worst."

\section{Mary Ridding.}

\section{T. W. Rhys Davids: The Scholar}

Professor T. W. Rhys Davids' career as a Pali scholar may be studied under the three heads of Philology, Translation, and History.

His writings on the Inscriptions of Ceylon (JRAS. 1875), the Ancient Coins and Measures of Ceylon (1877), and his paper on Pali and Sinhalese to the Philological Society (1875) announced the coming of a scholar, well equipped with the necessary training for research involving much labour and examination of minute details. The work of the Pali Text Society, which he founded on the lines of the Early English Text Society, is a monument of his scholarship and philological attainments. With characteristic foresight he had realized that critical editions of texts were needed if he was to succeed in convincing the West that the Buddhist movement was as instructive a study as Christianity in the history of religious thought. They would, moreover, form a basis for further study and progress in the interpretation of Buddhism. In this undertaking he displayed great powers of organization and a tremendous capacity for taking pains. Funds were collected and manuscripts acquired on loan or by purchase from Ceylon, Burma, and Siam; the services of editors, Occidental and Oriental, monks and laymen, men and women, were enlisted, and the collated texts printed off with unfailing regularity. The result shows that during forty years sixty-four texts in ninety-four volumes, extending over 26,000 pages, were issued by the Society. True, the actual number of edited works that bear his name on the title-page is small, and some may have wished that he could have edited more. But the extent of his work is to be estimated not only in figures, but also by the influence that he exercised on other editors, for he supplied many of them with the necessary materials and advice. Thus it may be said that a certain number of the texts which do not bear his name are the outcome of his own editing, whether his help is explicitly acknowledged or not. His own editions are a model of what edited texts should 
be. There are at least one or two texts in the Pali Text Society series that show that the editor is not familiar with his text, but has, as it were, mechanically followed the order of the words without much attention to punctuation. Sometimes essential phrases and even whole sentences are omitted, and, what is still worse, the better readings are often to be found in the footnotes-unmistakable evidence of the editor's incompetence. Rhys Davids was far too conscientious a scholar to edit his texts in this way. His method was this: The various readings are selected with judicious care, references to parallel passages are registered in footnotes, and main words and expressions collected in indices. And the completed text bears witness that he has digested, or at least has done his best to digest, the subject-matter. And he never fails to discuss somewhere or other the various rare forms and phrases and doubtful passages that he has met with. Excellent as would undoubtedly have been his work if he had edited more of the texts than he has actually done, it was well that he did not. His philological training and organizing powers were wanted for another big undertaking.

Childers had realized the importance of compiling a dictionary for the proper study of the texts that were being issued by Fausböll and a few others. His Pali Dictionary, a monument of learning and scholarship, was completed in 1875 . Rhys Davids welcomed it as " the most valuable contribution that had yet been made to the study of that language, but it was the indispensable means by which further progress could be made. Like Wilson's (Sanskrit Dictionary), it was sure to be superseded, for it made possible that rapid advance in the publication of Pali texts which has been the most marked feature in Oriental studies since its appearance". His own undertaking of the Pali Text Society is proof of the progress that has been made in the publication of texts. And in the spirit of progress he, too, realized that a dictionary more comprehensive than Childers's was needed to do justice to the newly published texts. He had made an immense store of new material, and formed a scheme of co-operation on international lines. The war put an end to the scheme, and, after "many cruel rebuffs and disappointments", Rhys Davids, assisted by Dr. Stede, brought out the first instalment in 1921. The amount of labour that Rhys Davids must have bestowed on the work can only be realized by those who know what it is to find adequate English terms and expressions for many of the elusive Buddhist words. The best criticism is offered by Rhys Davids himself: "This work is essentially 
preliminary. There is a large number of words of which we do not know the derivation. There is a still larger number of which the derivation does not give the meaning, but rather the reverse. It is so in every living language. Who could guess, from the derivation, the complicated meaning of such words as 'conscience', 'emotion', 'disposition'? The derivation would be as likely to mislead as to guide. We have made much progress. No one needs now to use the one English word 'desire' as a translation of sixteen distinct Pali words not one of which means precisely desire. Yet this was done in vol. $\mathrm{x}$ of the Sacred Books of the East, by Max Müller and Fausböll. The same argument applies to as many concrete words as abstract ones. Here, again, we claim to have made much advance." It is comforting to be assured of the progress and advance made, and the editors will earn the gratitude of every student, to whom the Dictionary will be a boon. Those words which are left unsolved will continue to defy solution for some time to come, when we consider that two such scholars as the present editors have done their best to solve them.

The treasures of thought buried in these old Pali texts would be of no avail without adequate translations. From the outset Rhys Davids was busy making translations. His aim was to educate the public, as well as to convince the scholar. He possessed the gift of producing scholarly translations in an attractive form. He infused the glow of life into the dry bones of Buddhist studies. He never overloaded his translations with superfluous notes. He always captured the reader's interest, if not his opinion. These merits were discerned in his earliest translation, Buddhrst Birth Stories (1880), in which he appealed to the general public by his treatment of such interesting topics as the migration of the Buddhist stories to the West, the origin of Essop's fables, and the various problems connected with the original text. The same method was applied in his Questions of Milinda (1890-4), which, besides being an excellent translation, added much to our knowledge on such points as the date and authorship of the text, its value as a work of art, and the identity of Milinda and Menander. But his masterpiece was his last work of translation, The Dialogues of the $B u d d h a$, the first volume of which was published in 1899 . Here he was at his best as a sympathetic exponent of the various phases of Indian beliefs. In his masterly introductions to the Suttas he translated, he made us familiar with the importance and age of the Nikayas, the differing views of the soul-theory, and the origin of the caste-system. He gave us an insight into the character of each and every type of men

vOL. III. PAR' I. 
under the vow of religion. Let us not forget, to his credit, that such varied and competent information was given at a time when scholars held not very clear notions on these points. In the later volumes of the Dialogues Rhys Davids had the assistance of his accomplished wife.

These undertakings - the Pali Text Society and the translations, together with the numerous articles in various Oriental Journalswould have been sufficient to do credit to any man. But Rhys Davids has done more: he was a historian. His attitude towards Buddhism may be defined in his own words: The story of Buddhism was to him the story "of the everyday beliefs and customs of a people nearly related to ourselves just as they were passing through the first stages of civilization ... of that interesting system of religion so nearly allied to some of the latest speculations among ourselves, and which has influenced so powerfully and for so long a time so great a portion of the human race-the system of religion which we now call Buddhism... of the only religious movement in the world's history which bears any close resemblance to Christianity". Again, "This Buddhist idea of the perfect life has an analogy most instructive from an historical point of view with the ideals of the last pagan thinkers in Europe before the rise of Christianity and of the modern exponents of what has been called fervent atheism". In this spirit he wrote his Buddhism (1878), the success of which was attested by the issue of the twentythird edition in 1914. His insight enabled him to prove that nirvana was not annihilation, but " a moral condition, to be reached here, in this world, and in this life", a view which has stood the test of later research. His Hibbert and American Lectures (1896) were written even in a more popular style.

Rhys Davids never lost sight of the close relation between the religion and the literature. In Buddhism, religion, it may be said, is literature, and literature religion. He treated both in Buddhist India (1903), his best work from the historical point of view. The chapters on the introduction of writing into India, the settling of the relative ages of the works composing the Canon, the priority of Pali over Sanskrit, are models of clear exposition and logical thinking. Those on the Brahman position, animism, and the Buddhist kings show the breadth of his outlook and the depth of his insight. His maturest views on the religion are given in Early Buddhism (1908).

Expter College, Oxford.

Pe Maung Tin. 